\title{
USE OF USED FOUNDRY SAND IN CONCRETE: A STATE OF ART
} REVIEW

\author{
Smit M. Kacha', Abhay V. Nakum², Ankur C. Bhogayata ${ }^{3}$ \\ ${ }^{1}$ PG Student, ${ }^{2}$ Assistant Professor, Civil Engineering Department, ${ }^{3}$ Associate Professor \& Head, Civil Engineering \\ Department, Marwadi Education Foundation, Gujarat, India
}

\begin{abstract}
This state of art review represents the development in the field of utilization of used foundry sand in cementitious concrete. The paper reviews the utilization of foundry sand as the concrete constituent and the noticeable and important findings from the experimental works of various researchers. The historical development is also discussed as a part of introduction in the review. After a careful study of large number of research papers on the topic it was felt by the authors to integrate all the important results for streamlining the potential of this area of research. The paper summarizes conclusions of experiments conducted for the properties like strength and durability. It was observed the results have shown positive changes and improvement in strength and durability properties of the conventional cementitious concrete due to the addition or replacement of fine sand with used foundry sand in different proportions. However in couple of cases such addition has reported reduction in the values of properties. From the review of past research works it could be concluded that utilizing the used foundry sand holds a great potential towards the development of environment friendly and sustainable cementitious concretes.
\end{abstract}

Key Words: foundry waste, foundry sand, concrete, strength, durability, utilization

\section{INTRODUCTION}

The Waste generated from the industries cause environmental problems. Hence the reuse of this Waste material can be emphasized. Foundry sand is high quality silica sand that is a byproduct from the production of both ferrous and nonferrous metal casting Industries.

Foundry sand used for the centuries as a molding casting material because it's high thermal conductivity. The physical and chemical characteristics of foundry sand will depend in great part on the type of casting process and the industry sector from which it originates.

In the casting process, molding sands are recycled and reused multiple times. Eventually, however, the recycled sand degrades to the point that it can no longer be reused in the casting process. At that point, the old sand is displaced from the cycle as byproduct, new sand is introduced, and the cycle begins again.

Two general types of binder systems are used in metal casting depending upon which the foundry sands are classified as: clay bonded systems (Green sand) and chemically- bonded systems. Both types of sands are suitable for beneficial use but they have different physical and environmental characteristics.

Over the last decades, much research has been conducted on the mechanical, chemical and durability aspects of foundry sand [10]. But inadequate research focus is given to the study of the strength and durability aspects of foundry sand concrete.

\section{LITERATURE REVIEW}

Several authors have reported the use of used foundry sand in various civil engineering applications. Tarun Naik [1] and their fellows investigated the performance of fresh and hardened concrete containing discarded foundry sand in place of fine aggregate. Concrete mixes were proportioned to replace $25 \%$ and $35 \%$ by weight of regular concrete sand with clean/new foundry sand and used foundry sand. The results of this investigation showed that mix containing $25 \%$ discarded foundry sand showed about $10 \%$ higher compressive strength at 28 days than the mix containing $35 \%$ discarded foundry sand. However, the compressive strength of the control mix was about $20-30 \%$ higher than the mixes containing discarded foundry sands. They added that no marked difference was observed in the density of fresh and hardened concrete.

Han-Young [3] investigated two types of Foundry Sands like clay bonded sand (CLW) and silicate bonded sand (COW) as a fine aggregate for concrete and basic properties such as air contents, setting time, bleeding, workability and slump loss of the fresh concrete with WFS were tested and compared with those of the concrete mixed without WFS. Also compressive strength and tensile strength of hardened concrete of 28 days were measured. The results showed that (i) flow value and compressive strength of mortar is very rapidly decreased with increasing the replacement ratio of COW and CLW; (ii) Bleeding of concrete with COW, CLW are decreased according to increasing replacement ratio of COW and CLW; (iii) concrete mixed with COW of $30 \%$, compressive and tensile strengths of concrete are higher than those of any other concrete without COW, whereas concrete mixed with CLW, compressive and tensile 
strengths of concrete are a bit smaller than that of control concrete.Rafat Siddique [4] investigated the mechanical properties of concrete mixtures in which fine aggregate was partially replaced with used foundry sand with three percentages $10 \%, 20 \%$ and $30 \%$ by weight. Tests were performed for the properties of fresh concrete, compressive strength, splitting tensile strength, flexural strength and modulus of elasticity were determined at 28, 56, 91 and 365 days. Test results showed that increase in compressive strength varied between $8 \%$ and $19 \%$ depending upon UFS percentage and testing age, whereas it was between $6.5 \%$ and $14.5 \%$ for splitting tensile strength, $7 \%$ and $12 \%$ for flexural strength and $5 \%$ and $12 \%$ for modulus of elasticity.

Saveria [5] investigated the properties of mortars and concretes containing different dosages of used foundry sand (UFS) as partial replacement of sand. The results showed that (i) UFS addition gives low slump; (ii) mortars containing UFS at water cement ratio equal to 0.5 show a compressive strength lower by about $20-30 \%$ compared to that of the reference mix; (iii) the modulus of elasticity doesn't vary significantly; (iv) Drying shrinkage increases with the decrease of mechanical performances.

Khatib and Baig [6, 7] investigated fresh and hardened properties of concrete containing waste foundry sand (WFS) replaced with 0 to $100 \%$ with fine aggregate. The water to cement for all mixes was kept constant. Testing on hardened properties was mainly conducted at 14, 28 and 56 days. The results show that the incorporation of waste foundry sand in concrete causes a systematic decreases in workability, ultrasonic pulse velocity and strength and an increase in water absorption and shrinkage of concrete. They also reported that an acceptable concrete strength can be achieved using foundry sand.

Kumbhar [8] investigated the various mechanical properties of concrete containing used foundry sand. Concrete was produced by replacing natural sand with UFS in various percentages $(10 \%, 20 \%, 30 \%$ and $40 \%)$. Based on the test results they concluded that (i) workability goes on reducing with increase in UFS content; (ii) At 28-days, Compressive strength, splitting tensile strength and flexural tensile strength for different replacement levels of UFS is increased whereas flexural tensile strength goes on reducing for UFS content more than 20\%; (iii) At 28-days, the modulus of elasticity values increases with replacement of UFS up to $20 \%$. They also concluded that the UFS can be utilized as a replacement to regular sand in concrete up to about $20 \%$.

L Da Silva and their team [11] investigated the influence of the use of foundry sand waste (FSW) on concrete properties. The properties on the fresh state were evaluated by means of flow table test and the determination of the incorporated air content. On the hardened state, compressive strength tests were performed. Their initial results have shown that the use of FSW leads to an increase in the air content and cracking, caused by expansive reactions. As a result of that, a reduction in the compressive strength has been noticed. They added that the application of mixtures made with FSW becomes risky as to the structural and durability requirements. However they also added that their work may not be generalized, because the FSW composition varies according to the manufacturing process and in all cases it is advisable to carry out preliminary tests in order to verify the effects caused by the use of FSW in the concrete production.

Gurpreet Singh and Rafat Siddique [12, 13] investigated the strength and durability properties of concrete mixtures, in which natural sand was replaced with five percentage $(0 \%$, $5 \%, 10 \%, 15 \%$ and $20 \%$ ) of waste foundry sand (WFS) by weight. Compression test and splitting tensile strength test were carried out at the age of 7,28 and 91 days and Modulus of elasticity, ultrasonic pulse velocity and Rapid Chloride Permeability test were conducted at the age of 28 and 91 days. The abrasion resistance of concrete containing WFS was also investigated. Based on the results obtained they concluded that (i) Maximum increase in compressive strength, splitting tensile strength and modulus of elasticity of concrete was observed with $15 \%$ WFS, both at 28 and 91 days; (ii) WFS increases the ultrasonic pulse velocity values and decreased the chloride ion penetration in concrete; (iii) Abrasion resistance of concrete increased with the increase in WFS content. They also added that WFS can be suitably used in making structural grade concrete, as well as for applications where abrasion is also important parameter.

Khatib and Herki [16] investigated the concrete produced by replacing the fine aggregates with $0 \%, 30 \%, 60 \%$ and $100 \%$ WFS. The water content, coarse aggregate, cement and the water to cement ratio remained constant. The properties investigated at 7, 28 and 90 days curing times. The results indicate that there is systematic increase in water absorption by capillary action, a decrease in compressive strength and Ultrasonic pulse velocity with increasing amounts of WFS in concrete. They also reported that adequate strength can be achieved using an appropriate replacement level of foundry sand.

Eknath [17] investigated the comparative study of the properties of fresh \& hardened concrete containing ferrous $\&$ non-ferrous foundry waste sand replaced with four $(0 \%$, $10 \%, 20 \%$ and $30 \%$ ) percentage by weight of fine aggregate $\&$ tests were performed for M20 grade concrete. Result showed that (i) addition of both foundry sand gives low slump mainly due to the presence of very fine binders; (ii)

Compressive strength at 7 days of both ferrous $\&$ nonferrous mixtures increases and maximum increase was observed with $20 \%$ WFS of both types of sand, at 28 days $30 \%$ addition of ferrous WFS \& $10 \%$ addition of nonferrous WFS gives same strength as ordinary concrete and goes on decreasing for higher percentages of replacement; (iii) Split tensile strength gives maximum values with $20 \%$ WFS for both types of sand; (iv) water absorption is minimum with $20 \%$ ferrous WFS \& with $10 \%$ nonferrous WFS. They also reported that both ferrous \& nonferrous WFS can be suitably used in making structural grade concrete. 


\section{DISCUSSION}

Based on various researchers, it is observed that $20 \%$ replacement generally gives higher strength compared to normal concrete. All the researchers noticed fresh concrete behavior with foundry sand that workability is decreases with the increase of foundry sand content by slump test or flow table test. Most of the researchers noticed positive changes in the concrete containing foundry sand in terms of compressive strength and tensile strength where there is not much change occurs in modulus of elasticity. Also, Water absorption increases as replacement of foundry sand increases. Also it shows that foundry sand decreases the chloride ion penetration in concrete. However all researchers have noticed that concrete incorporation with foundry sand can be suitably used in making structural or nonstructural grade concrete. It could also be noted that the effects of concrete containing foundry sand shall be differs as the foundry sand changes its characteristics according to its manufacturing process and source.

\section{CONCLUSION}

Based upon above literature review it could be concluded that all researchers gave their findings with concrete up to $30-40 \%$ replacement of fine aggregate with foundry sand in which compressive and tensile strength is increased up to $20 \%$ whereas not much change occurs in modulus of elasticity. Also workability is decreases with the increase of foundry sand content because of very fine particles. However all researchers noted that concrete made with foundry sand can be suitably used in making structural grade concrete. But, very few researchers go up to $100 \%$ replacement where strength and durability criteria needed to be studied further effectively in future.

\section{REFERENCES}

[1] Tarun R. Naik, Viral M. Patel, Dhaval M. Parikh, Mathew P. Tharaniyil, "Utilisation of used foundry sand in concrete", Journal of Materials in Civil Engineering, Vol. 6, No. 2, May, 1994.

[2] Foundry Industry Recycling Starts Today (FIRST), Foundry Sand Facts for Civil Engineers, Federal Highway Administration Environmental Protection Agency Washington, DC; 2004.

[3] Han-Young Moon, Yun-Wang Choi, Youg-Kyu Song and Jung-Kyu Jeon, "Fundamental properties of Mortar and Concrete using waste foundry sand", Journal of the Korea Concrete Institute, Vol.17, No.1, pp.141-147, February 2005.

[4] Rafat Siddique, Geert de Schutter, Albert Noumowe, "Effect of used-foundry sand on the mechanical properties of concrete", Elsevier, Construction and Building Materials 23 (2009) 976-980.

[5] Saveria Monosi, Daniela Sani and Francesca Tittarelli, "Used foundry sand in cement mortars and concrete production", The Open Waste Management Journal, Vol.3, ISSN 1876-4002, pg.18-25, 2010.

[6] J. M. Khatib, S. Baig, A Bougara and C Booth, "Foundry sand utilization in concrete production", Second
International Conference on Sustainable Construction Materials and Technologies, ISBN 978-1-4507-1490-7, June 28-30, 2010.

[7] Khatib.J.M, Baig.B, Menadi.B, Kenai.S, "Waste foundry sand usage in concrete", INVACO2, Morocco-Rabat, November 23-25, 2011.

[8] Kumbhar P. D. and Usharani S. Sangar, "Experimental study of mechanical properties of concrete blended with used foundry sand", Global Journal Engineering and Applied Sciences, ISSN 2249-2631, Pg.122-126, 2011.

[9] Rafat Siddique, Yogesh Aggarwal, Paratibha Aggarwal, El-Hadj Kadri, Rachid Bennacer, "Strength, durability, and micro-structural properties of concrete made with usedfoundry sand (UFS)", Elsevier, Construction and Building Materials 25 (2011) 1916-1925.

[10] S. L. Bradshaw, C. H. Benson, E. H. Olenbush J. S. Melton, "Using foundry sand in green infrastructure construction", Green Streets and Highways 2010, ASCE 2011.

[11] W.R. L Da Silva, E.Tochetto, L.R. Prudencio Jr., A.L. Oliveira, "Influence of foundry sand residues on the fresh and hardened properties of mortars produced with Portland cement", Ibracon Structures and Materials Journal, ISSN 1983-4195, Volume 4, Number 4 (October, 2011), p. 642662.

[12] Gurpreet Singh, Rafat Siddique, "Effect of waste foundry sand (WFS) as partial replacement of sand on the strength, ultrasonic pulse velocity and permeability of concrete", Elsevier, Construction and Building Materials 26 (2012) 416-422.

[13] Gurpreet Singh, Rafat Siddique, "Abrasion resistance and strength properties of concrete containing waste foundry sand (WFS)", Elsevier, Construction and Building Materials 28 (2012) 421-426.

[14] H. Merve Basar, Nuran Deveci Aksoy, "The effect of waste foundry sand (WFS) as partial replacement of sand on the mechanical, leaching and micro-structural characteristics of ready- mixed concrete", Elsevier, Construction and Building Materials 35 (2012) 508-515.

[15] Johnny Bolden, Taher Abu-Lebdeh and Ellie Fini, "Utilization of recycled and waste materials in various construction applications", American Journal of Environmental Science, 9 (1), ISSN: 1553-345X, Pg.14-24, 2013.

[16] J.M. Khatib, B.A. Herki, S. Kenai, "Capillarity of concrete incorporating waste foundry sand", Elsevier, Construction and Building Materials 47 (2013) 867-871. [17] Eknath P. Salokhe, D. B. Desai, "Application of foundry waste sand in manufacture of concrete", IOSRJMCE, ISSN: 2278-1684, PP: 43-48. 


\section{BIOGRAPHIES}

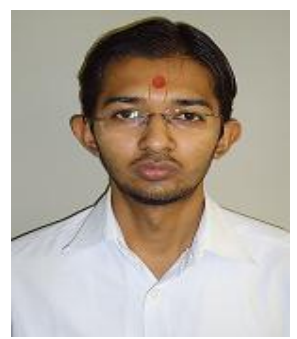

Smit Mahendrabhai Kacha was born in 1990 in Savarkundla, Gujarat. He receives his Bachelor of Engineering degree in Civil Engineering from the C. K. Pithawala College, Veer Narmad South Gujarat University in 2011. At present he is Final year student of Master's degree in Structural engineering from Marwadi Education Foundation Group of Institutions, Gujarat Technological University.

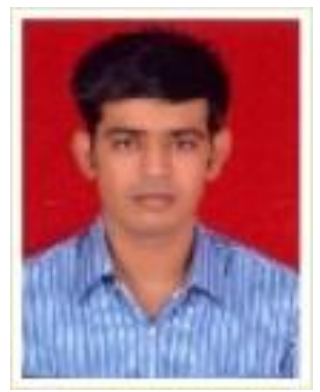

Prof. Abhay V. Nakum was born in 1990 in Jamkhambhaliya, Gujarat. $\mathrm{He}$ received his Bachelor of Engineering degree from L. D. Engineering College, Gujarat University in 2011. In 2013 he received his Master's Degree in Structural Engineering from Marwadi Education Foundation Group of Institutions, Gujarat Technological University. He joined Marwadi Education Foundation Group of Institutions as a Assistant Professor of Civil Engineering Department. He has paper published in International Journal.

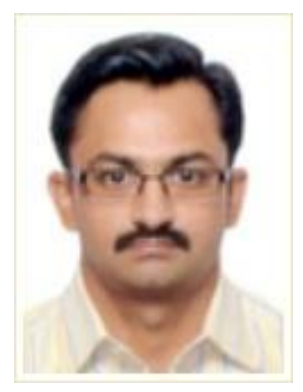

Prof. Ankur C. Bhogayata received his Bachelor of Engineering Degree in Civil Engineering from the in 1999. In 2001 he received his Master's Degree in Structural Engineering from BITS, Pilani. He joined Marwadi Education Foundation's Group of Institutions as a faculty where he is Associate Professor \& Head of Civil Engineering Department with a total experience of 10 years. He is guiding M.E. Thesis work in field of Civil Engineering. He has papers published in National Conferences and International Journals. 